Article

AGOSTINETTO, D. ${ }^{*}$

TAROUCO, C.P. ${ }^{1}$

LANGARO, A.C. ${ }^{1}$

GOMES, J. ${ }^{1}$

VARGAS, L. ${ }^{2}$

\section{COMPETITION BETWEen WHEAT AND RYEGRASS UNDER Different LeVels OF Nitrogen Fertilization}

\section{Competição de Trigo e Azevém sob Diferentes Niveis de Adubação Nitrogenada}

ABSTRACT - The main limiting factors for the productive potential of wheat crops are related to the competition with weeds for resources such as water, light and nutrients. Nitrogen $(\mathrm{N})$ is an important nutrient used to maintain crop productivity, as well as promoting the competitive ability of crops and therefore suppress the weed growth. In this context, the goal of this study was to evaluate the effects of wheat plants in competition with ryegrass under different levels of nitrogen fertilization. Treatments were arranged in a factorial design, where factor A consisted in nitrogen rates $\left(0,60,120,180\right.$ and $\left.240 \mathrm{~kg} \mathrm{ha}^{-1}\right)$ and factor $\mathrm{B}$ consisted in ryegrass and wheat plants ratios, which were: 100/0 (pure stand of 64 wheat plants), 50/50 (32 wheat plants and 32 ryegrass plants) and 0/100 (pure stand of 64 ryegrass plants). Competition between the culture and ryegrass by $\mathrm{N}$ resulted in mutual damages, but the culture was more competitive than weeds, regardless of the $\mathrm{N}$ dose. The use of doses up to $120 \mathrm{~kg} \mathrm{~N} \mathrm{ha}^{-1}$ increased the evaluated variables for wheat and ryegrass. Interspecific competition and nitrogen in higher than $120 \mathrm{~kg} \mathrm{~N} \mathrm{ha}^{-1}$ doses reduced the morphological variables mass of the aerial part dry matter and leaf area of wheat and ryegrass.

Keywords: nitrogen, replacement series, Triticum aestivum, Lolium multiflorum.

RESUMO - Os principais fatores limitantes do potencial produtivo da cultura do trigo estão relacionados à competição das plantas daninhas por recursos como água, luz e nutrientes. O nitrogênio $(N)$ é importante nutriente utilizado para manter a produtividade das culturas, além de favorecer a habilidade competitiva da cultura e, com isso, suprimir o crescimento das plantas daninhas. Nesse contexto, o objetivo deste trabalho foi avaliar os efeitos da competição de plantas de trigo e azevém sob diferentes níveis de adubação nitrogenada. Os tratamentos foram arranjados em esquema fatorial, em que ofator A constituiu-se de doses de nitrogênio (0, 60, 120, 180 e $\left.240 \mathrm{~kg} \mathrm{ha}^{-1}\right)$ e o fator B, de proporções de plantas de azevém e trigo, as quais foram: 100/0 (estande puro de 64 plantas de trigo), 50/50 (32 plantas de trigo e 32 plantas de azevém) e 0/100 (estande puro de 64 plantas de azevém). A competição entre a cultura e o azevém pelo $N$ acarretou prejuizo mútuo, porém a cultura mostrou maior competitividade do que a planta daninha, independentemente da dose de N. A utilização de doses até $120 \mathrm{~kg} \mathrm{~N} \mathrm{ha}^{-1}$ aumentaram as variáveis avaliadas para o trigo e para o azevém. A competição interespecifica e o nitrogênio nas doses superiores a $120 \mathrm{~kg} \mathrm{~N} \mathrm{ha}^{-1}$ reduziram as variáveis morfológicas massa da matéria seca da parte aérea e área foliar do trigo e do azevém.

Palavras-chave: nitrogênio, série substitutiva, Triticum aestivum, Lolium multiflorum.
Received: July 25, 2016

Approved: September 8, 2016

Planta Daninha 2017; v35:e017165037

1 Universidade Federal de Pelotas, Faculdade de Agronomia Eliseu Maciel; Pelotas-RS, Brasil; ${ }^{2}$ Embrapa Trigo; Passo FundoRS, Brasil. 


\section{INTRODUCTION}

Wheat is the second most produced cereal in the world; the Brazilian production is 5.5 million tons, occupying the $20^{\text {th }}$ position in the world ranking (Conab, 2016). Competition for nutritional resources is considered one of the limiting factors in the maintenance of culture productivity. Competition with weeds causes great losses in wheat productivity, creating an increase in production costs with the use of herbicides; this makes cultivation less and less economically attractive (Lamego et al., 2013). Wheat cultivars with high competitive ability with weeds present characteristics such as higher plant height, large and decumbent leaves, vigorous growth, tillering capacity and soil covering (Lemerle et al., 2001).

Among the weeds infesting wheat cultures, it is possible to highlight ryegrass (Lolium multiflorum); it presents morpho-physiological similarities with the culture in terms of development, height, canopy architecture and resource demand, since they belong to the same botanical family.

Management practices that may increase the competitive capacity between cultures and weeds are important tools in cultivation systems. Fertilization management is one of these practices; it can change the interference between culture and competitor (Liebman and Janke, 1990; Ditomaso, 1995). Studies reported that N increased the competitive capacity of weeds over cultures (Santos et al., 1998; Dhima and Eleftherohorinos, 2001; Andreasen et al., 2006) or that it benefited cultures in the presence of weeds (Mishra and Kurchania, 2001; Evans et al., 2003; Cathcart and Swanton, 2004; Abouziema et al., 2007).

Plants present different response capacities to $\mathrm{N}$ soil contents (Blackshaw et al., 2003). However, it is not clear how nitrogen availability may change the competition among plants. Considering the abovementioned, the goal of this work was to evaluate the competitive ability of wheat and ryegrass plants under different levels of nitrogen fertilization.

\section{MATERIAL AND METHODS}

Two experiments were conducted in a greenhouse, in completely randomized design with four replications for the first and second experiment respectively. The first had the goal to determine the plant population $\mathrm{m}^{-2}$ from which dry matter mass from the aerial part (APDMM) per area unit $\left(\mathrm{g} \mathrm{m}^{-2}\right)$ becomes independent from the population (Radosevich et al., 2007). The tested populations, in wheat and ryegrass species monocultures, were from 4 to 128 plants per planter. Competitor species were Horizonte wheat (precocious cycle) and ryegrass biotype (Lolium multiflorum) crops, planted in vases with an eight liter volumetric capacity and $23 \mathrm{~cm}$ diameter, filled with sandy loam texture Red-Yellow Argisol, belonging to the Pelotas mapping unit (Embrapa, 2009). Soil fertilizing correction was made based on soil analysis, according to the recommendations for wheat culture (Comissão..., 2011).

The APDMM variable was quantified on day 30 and 60 after emergence (DAE), by weighing the aerial part of plants after being dried in a greenhouse with forced air circulation at $60^{\circ}$ for 72 hours. Constant APDMM was observed, with a population of 64 plants per planter, that is, 1,542 plants $\mathrm{m}^{-2}$ for culture and weed (data not presented).

For the second experiment, treatments were arranged in a factorial scheme, where factor A was composed by nitrogen doses $\left(0,60,120,180\right.$ and $\left.240 \mathrm{~kg} \mathrm{ha}^{-1}\right)$ and factor B was composed by ryegrass and where plant proportions: which were: 100/0 (pure wheat stand), 50/50 (32 wheat plants and 32 ryegrass plants) and 0/100 (pure $r$ stand). The population of ryegrass and wheat $(50 / 50)$ corresponded to the competition condition with an equivalent population of 64 plants per pot, evenly distributed, as determined in experiment 1 . The coverage application of nitrogen in the form of urea was performed at the beginning of the tillering stage, corresponding to 15 days after wheat emergence (DAE), Feeks 1 scale, according to Large (1954).

In order to analyze data from the leaf area (LA) and APDMM variables of ryegrass and culture, the method of the relative productivity graphic analysis was used (Cousens, 1991; Radosevich et al., 2007). The referred procedure consists in the creation of diagrams based on the productivities or the relative (RP) and total (TPR) variations. When the result of the RP tends to a 
straight line, it means that the species abilities are equivalent. If the RP results in a concave line, it indicates that there is damage in the growth of one or both species. On the other hand, if the RP results in a convex line, there is a benefit in the growth of one or both species. When the TPR is equal to 1 (straight line), there is competition for the same resources; if it is higher than 1 (convex line), competition is avoided. If the TPR is lower than 1 (concave line), there is mutual damage to growth (Cousens, 1991; Radosevich et al., 2007).

In addition to RP and TPR, results obtained for LA and APDMM of wheat and ryegrass plants, expressed in average values per plant, were submitted to analysis of variance. Relative competitiveness $(\mathrm{RC})$ indices and relative cluster $(\mathrm{K})$ and competitiveness $(\mathrm{C})$ coefficients were calculated. $\mathrm{RC}$ represents the comparative growth of the $\mathrm{X}$ species (wheat) in relation to $\mathrm{Y}$ (ryegrass); $\mathrm{K}$ indicates the relative dominance of a species over the other; and $\mathrm{C}$ indicates which species is more competitive. Thus, $\mathrm{RC}, \mathrm{K}$ and $\mathrm{C}$ indices indicates which species is the most competitive, and their joint interpretation indicates the species competitiveness (Cousens, 1991). The $\mathrm{X}$ species is more competitive than $\mathrm{Y}$ when $\mathrm{RC}>, \mathrm{K}_{\mathrm{x}}>\mathrm{K}_{\mathrm{y}}$ and $\mathrm{C}>0$; on the other hand, the $\mathrm{Y}$ species is more competitive than $\mathrm{X}$ when $\mathrm{RC}<1, \mathrm{~K}_{\mathrm{x}}<\mathrm{K}_{\mathrm{y}}$ and $\mathrm{C}<0$ (Hoffman and Buhler, 2002). They are calculated using 50/50 proportions of the species.

The procedure for statistical analysis of productivity or relative variation includes the calculation of the differences for the RP values, obtained in 50 and 100 proportions, in relation to the values belonging to the hypothetical line in the respective proportions (Bianchi et al., 2006). The $\mathrm{T}$ test was used to evaluate the differences relating to RP, TPR, RC, $\mathrm{K}$ and $\mathrm{C}$ indices (Hoffman and Buhler, 2002). The criterion to consider RP and TPR curves that were different from the hypothetical lines and the existence of competitiveness difference was that, in at least two proportions, there should be differences (Bianchi et al., 2006).

\section{RESULTS AND DISCUSSION}

There was an interaction among the studied factors in competitors, proportions and nitrogen doses for the APDMM and LA variables. There was a reduction in the APDMM and LA of wheat and/or ryegrass plants, in general, when the $\mathrm{N}$ dose was higher than $120 \mathrm{~kg} \mathrm{ha}^{-1}$ (Figures 1 and 2). In addition, as for both variables, it was possible to observe a lower production during coexistence, compared to the monoculture. In the comparison among nitrogen doses, the maximum APDMM production by the wheat culture both in monoculture and mixed, was verified when 100 and $80 \mathrm{~kg} \mathrm{~N} \mathrm{ha}^{-1}$ were applied, respectively (Figure 1A). As for ryegrass, the maximum production was observed with the application of 116 and $118 \mathrm{~kg} \mathrm{~N} \mathrm{ha}^{-1}$, when isolated or in a mixture, respectively (Figure 1B).

According to the results, it was possible to observe that wheat used a lower $\mathrm{N}$ dose to produce more APDMM than ryegrass, both for monoculture and for the proportion in competition with ryegrass; it was possible to deduce that wheat has a higher capacity to use $\mathrm{N}$ than ryegrass. The same was found for barley (Hordeumvulgare), which was more competitive than ryegrass (Lolium rigidum), due to the fact that the early tillering of the culture, in relation to the weed, created a higher demand for nitrogen by the soil, making it the most competitive, not because of the quicker nitrogen absorption, but for the anticipation in its demand for this nutrient.

As for LA, the maximum production by the wheat culture both in monoculture and mixture, was verified when 95 and $101 \mathrm{~kg} \mathrm{~N} \mathrm{ha}^{-1}$ were applied, respectively (Figure 2A). As for ryegrass, the maximum production was observed with the application of 125 and $112 \mathrm{~kg} \mathrm{~N} \mathrm{ha}^{-1}$, in monoculture or mixture, respectively (Figure 2B). It was observed that the wheat culture, both for monoculture and for the 50/50 proportion, used the medium $\mathrm{N}$ more effectively than ryegrass. In both evaluated species, the interspecies competition was more damaging than the intraspecies, since the monoculture produced higher values for the variable.

As it was verified in similar studies, plants submitted to higher doses than $160 \mathrm{~kg} \mathrm{~N} \mathrm{ha}^{-1}$ did not present additional responses in the growth or yield of the plant (Burgos et al., 2006). The addition of $150 \mathrm{~kg} \mathrm{~N} \mathrm{ha}^{-1}$ helps the increase in the mass of wheat dry matter when it does not compete with weeds; however, in competition with Avena sterilis, wheat dry matter mass was lower when it received $\mathrm{N}$, compared to the treatment where plants did not receive this nutrient (Dhima and Eleftherohorinos, 2001). 

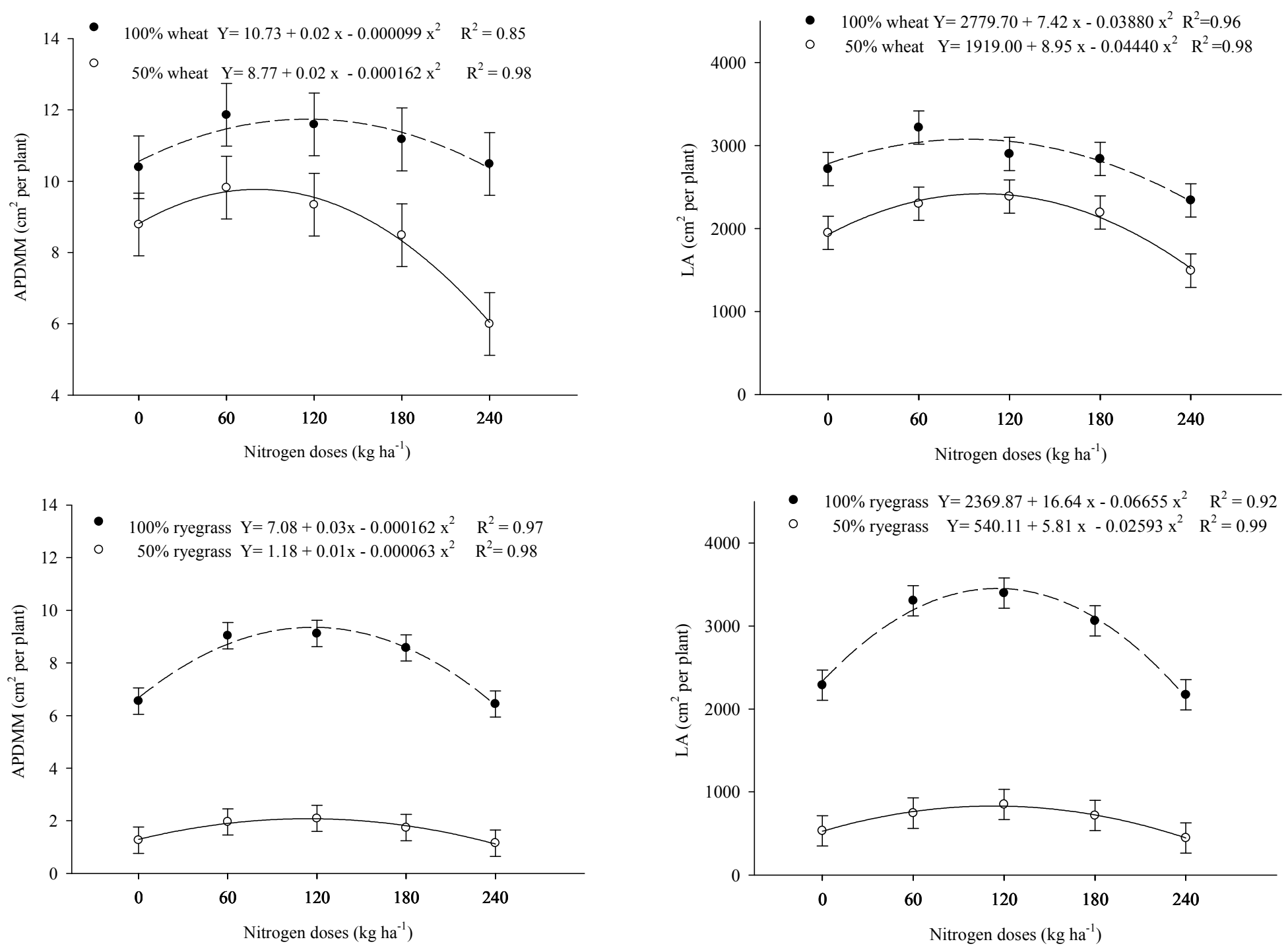

Empty circles $(\mathrm{O})$ and continuous lines represent the 50/50 proportion of wheat and ryegrass; full circles $(\bullet)$ and dashed lines represent the monoculture of wheat or ryegrass.

Figure 1 - Mass of the aerial part dry matter in wheat (A) and ryegrass (B) plants, in competition with nitrogen doses.

Empty circles $(\mathrm{O})$ and continuous lines represent the 50/50 proportion of wheat and ryegrass; full circles $(\bullet)$ and dashed lines represent the monoculture of wheat or ryegrass.

Figure 2 - Leaf area of wheat (A) and ryegrass (B) plants in competition with nitrogen doses.

In spite of the studies that demonstrated the importance of doses and application methods of nitrogen fertilizers in the competition between cultures and weeds, there are few available data about how weeds respond to increasing levels of $\mathrm{N}$ in the soil (Blackshaw and Brandt, 2008). The competition of Stellariamedia and wheat increased the weight and seed number of the weed with the increase of nitrogen levels in the soil (van Delden et al., 2002). On the other side, the competition of weeds in barley and wheat may be decreased or unchanged with higher $\mathrm{N}$ levels, depending on the weed (Jornsgard et al., 1996).

Nitrogen is the main nutrient added to increase the productivity of wheat, but it is not always known how this nutrient's levels may affect the competitive interaction between weeds and cultures (Blackshaw et al., 2003). Thus, the addition of this nutrient may have the nonintentional consequence of increasing the growth and competitive capacity of weeds more than the one of the culture (Blackshaw and Brandt, 2008).

In the graphic analysis for RP, referring to the APDMM and LA variables, the observed deviations from RP lines, in relation to the expected lines, are represented by concave lines, both for the culture and for ryegrass, in all evaluated doses (Figures 3 and 4), demonstrating 

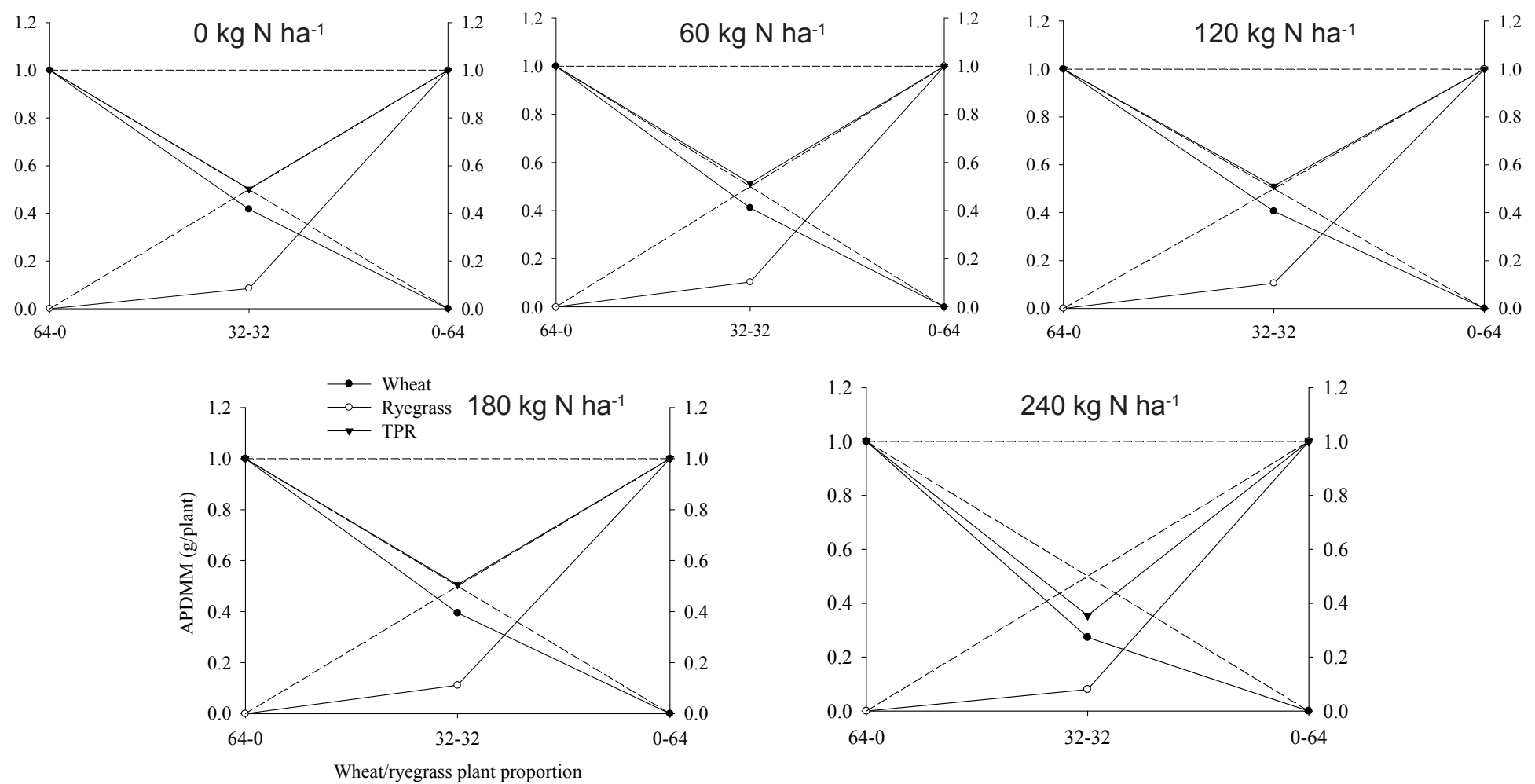

Empty circles (O) represent the RP of ryegrass biotype; full circles $(\bullet)$ represent the RP of wheat and triangles ( $\mathbf{\nabla})$ represent the TPR. Dashed lines refer to the hypothetical relative productivities, when there is no interference of one species over the other.

Figure 3 - Relative (RP) and total (TPR) productivity for APDMM of wheat and ryegrass plants with nitrogen doses.
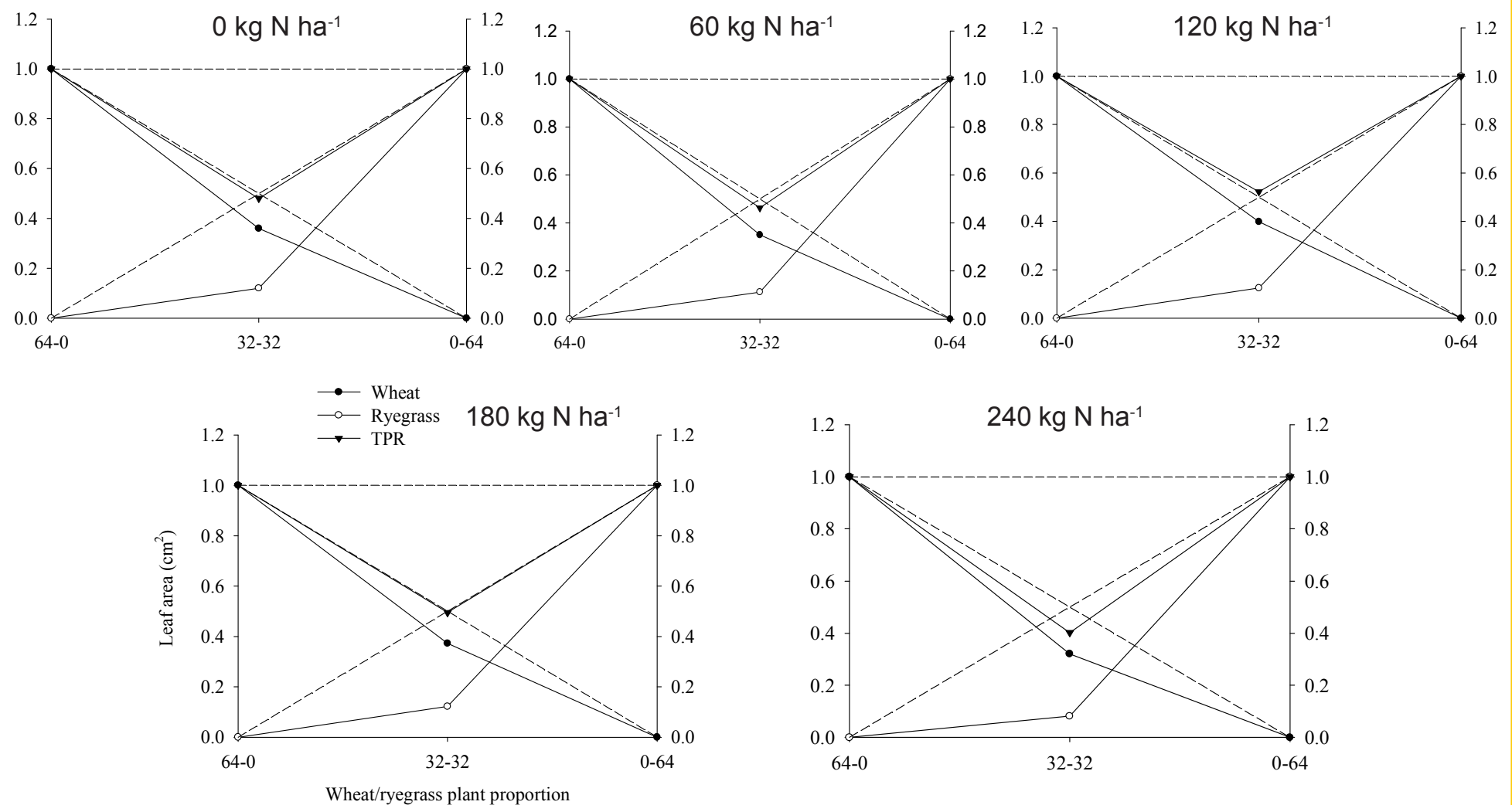

Empty circles $(\mathrm{O})$ represent the RP of ryegrass biotype; full circles $(\mathbf{O})$ represent the RP of wheat and triangles $(\boldsymbol{\nabla})$ represent the TPR. Dashed lines refer to the hypothetical relative productivities, when there is no interference of one species over the other.

Figure 4 - Relative (RP) and total (TPR) productivity for the LA of wheat and ryegrass plants with nitrogen doses. 
damages for both species in all used nitrogen doses. As for TPR, generally speaking, there was a difference between the expected and observed values for the studied variables (Table 1); values lower than 1 for the studied species were observed in all used doses. This means that the interaction between wheat and ryegrass happens by the same resource of the environment and there are damages for both species. In the comparison between proportion and control sample for APDMM and LA, both in wheat and ryegrass, it was observed that the monoculture presented an increase in the value of variables in relation to the proportion (Table 2). This indicates that both the culture and the competitor tolerate more the intraspecies competition. On the other hand, the application of $\mathrm{N}$ in higher doses increases the LA and ADPM of the wheat culture competing with ryegrass, as observed by Paula et al. (2011).

The relative growth of wheat was higher than the one of ryegrass; there was a dominance of the culture over the competitor, as indicated by the $\mathrm{RC}, \mathrm{K}$ and $\mathrm{C}$ indices (Table 3). It was observed that, for all variables, the culture had greater competitiveness than the weed in all used $\mathrm{N}$ doses. Similar results were found by Rigoli et al. (2008) and Scursoni et al. (2012), also highlighting that wheat was more competitive than ryegrass.

Table 1 - Relative differences for the APDMM and LA variables of wheat and ryegrass submitted to nitrogen doses $\left(\mathrm{kg} \mathrm{N}^{1}\right)$

\begin{tabular}{|l|c|c|c|c|c|}
\hline \multirow{2}{*}{} & \multicolumn{5}{|c|}{$50 / 50$ plant proportion } \\
\cline { 2 - 6 } & 0 & 60 & 120 & 180 & 240 \\
\cline { 2 - 6 } & \multicolumn{5}{|c|}{ WPDMM (g per plant) } \\
\hline RP t & $-0.08( \pm 0.02)^{*}$ & $-0.09( \pm 0.02)^{*}$ & $-0.09( \pm 0.02)^{*}$ & $-0.11( \pm 0.01)^{*}$ & $-0.23( \pm 0.02)^{*}$ \\
\hline RP a & $-0.42( \pm 0.01)^{*}$ & $-0.40( \pm 0.00)^{*}$ & $-0.39( \pm 0.01)^{*}$ & $-0.39( \pm 0.01)^{*}$ & $-0.42( \pm 0.01)^{*}$ \\
\hline TPR & $0.50( \pm 0.02)^{*}$ & $0.51( \pm 0.02)^{*}$ & $0.51( \pm 0.02)^{*}$ & $0.51( \pm 0.02)^{*}$ & $0.35( \pm 0.03)^{*}$ \\
\hline & \multicolumn{5}{|c|}{ LA } \\
\hline & \multicolumn{5}{|c|}{ Wheat:ryegrass } \\
\hline RP t & $-0.14( \pm 0.02)^{*}$ & $-0.15( \pm 0.02)^{*}$ & $-0.10( \pm 0.01)^{*}$ & $-0.13( \pm 0.01)^{*}$ & $-0.18( \pm 0.03)^{*}$ \\
\hline RP a & $-0.38( \pm 0.02)^{*}$ & $-0.39( \pm 0.02)^{*}$ & $-0.38( \pm 0.01)^{*}$ & $-0.38( \pm 0.01)^{*}$ & $-0.42( \pm 0.00)^{*}$ \\
\hline TPR & $0.48( \pm 0.03)^{*}$ & $0.46( \pm 0.03)^{*}$ & $0.52( \pm 0.01)^{*}$ & $0.50( \pm 0.02)^{*}$ & $0.40( \pm 0.03)^{*}$ \\
\hline
\end{tabular}

* Significant difference by $\mathrm{t}$ test $(\mathrm{p} \leq 0.05)$. Values in parentheses represent the standard error for the average.

Table 2 - Responses to the aerial part dry matter (APDMM) and leaf area (LA) for wheat in competition with ryegrass, submitted to nitrogen doses $\left(\mathrm{kg} \mathrm{N} \mathrm{ha}^{-1}\right)$

\begin{tabular}{|c|c|c|c|c|c|}
\hline \multirow{3}{*}{$\begin{array}{l}\text { Proportion } \\
(\mathrm{W} / \mathrm{R})\end{array}$} & \multicolumn{5}{|c|}{ Wheat } \\
\hline & \multicolumn{5}{|c|}{ APDMM (g per plant) } \\
\hline & 0 & 60 & 120 & 180 & 240 \\
\hline $100 / 0(\mathrm{~T})$ & $10.38^{*}$ & $12.32^{*}$ & $11.59 *$ & $10.54^{*}$ & $10.13^{*}$ \\
\hline \multirow[t]{2}{*}{$50 / 50$} & 8.78 & 9.81 & 9.33 & 8.48 & 5.60 \\
\hline & \multicolumn{5}{|c|}{ LA } \\
\hline $100 / 0(\mathrm{~T})$ & $2716.7 *$ & $3215.1^{*}$ & $3006.7 *$ & $2837.3^{*}$ & $2338.3^{*}$ \\
\hline $50 / 50$ & 1947.4 & 2231.2 & 2385.6 & 2116.4 & 1493.1 \\
\hline \multirow{3}{*}{$\begin{array}{l}\text { Proportion } \\
\text { (T:A) }\end{array}$} & \multicolumn{5}{|c|}{ Ryegrass } \\
\hline & \multicolumn{5}{|c|}{ APDMM (g per plant) } \\
\hline & 0 & 60 & 120 & 180 & 240 \\
\hline $0 / 100(\mathrm{~A})$ & $6.98^{*}$ & $9.03^{*}$ & $9.11 *$ & $8.57 *$ & $6.84 *$ \\
\hline \multirow[t]{2}{*}{$50 / 50$} & 1.15 & 1.96 & 1.94 & 1.87 & 1.11 \\
\hline & & & LA & & \\
\hline $0 / 100(\mathrm{~A})$ & $2285.5^{*}$ & $3304.3 *$ & $3395.0^{*}$ & $3061.1^{*}$ & $2615.2^{*}$ \\
\hline $50 / 50$ & 532.0 & 817.5 & 848.74 & 746.85 & 445.2 \\
\hline
\end{tabular}

Averages in the column followed by ${ }^{n s}$ and $*$ indicate non-significant and significant differences, respectively, by $t$ test $(p \leq 0.05)$, in relation to the control sample (T). 
Table 3 - Competitiveness indices between wheat and ryegrass, expressed by relative competitiveness (RC) and relative cluster $(\mathrm{K})$ and competitiveness $(\mathrm{C})$ coefficients were, submitted to nitrogen doses $\left(\mathrm{kg} \mathrm{N} \mathrm{ha}^{-1}\right)$

\begin{tabular}{|c|c|c|c|c|}
\hline \multirow{2}{*}{$\mathrm{N}$ doses } & \multicolumn{5}{|c|}{ APDMM (g per plant) } \\
\cline { 2 - 5 } & $\mathrm{CR}$ & $\mathrm{K}_{\mathrm{t}}$ & $\mathrm{K}_{\mathrm{a}}$ & $\mathrm{C}$ \\
\hline 0 & $5.19( \pm 0.71)^{*}$ & $0.71( \pm 0.04)^{*}$ & $0.09( \pm 0.01)$ & $0.33( \pm 0.02)^{*}$ \\
\hline 60 & $4.02( \pm 0.34)^{*}$ & $0.70( \pm 0.06)^{*}$ & $0.11( \pm 0.004)$ & $0.31( \pm 0.02)^{*}$ \\
\hline 120 & $3.93( \pm 0.34)^{*}$ & $0.68( \pm 0.01)^{*}$ & $0.11( \pm 0.01)$ & $0.30( \pm 0.02)^{*}$ \\
\hline 180 & $3.59( \pm 0.19)^{*}$ & $0.65( \pm 0.03)^{*}$ & $0.12( \pm 0.009)$ & $0.28( \pm 0.01)^{*}$ \\
\hline 240 & $3.39( \pm 0.12)^{*}$ & $0.38( \pm 0.03)^{*}$ & $0.08( \pm 0.006)$ & $0.19( \pm 0.02)^{*}$ \\
\hline & \multicolumn{5}{|c|}{$\mathrm{LA}\left(\mathrm{cm}^{2}\right.$ per plant $)$} & $0.24( \pm 0.02)^{*}$ \\
\hline 0 & $3.16( \pm 0.40)^{*}$ & $0.56( \pm 0.04)^{*}$ & $0.13( \pm 0.02)$ & $0.24( \pm 0.01)^{*}$ \\
\hline 60 & $3.10( \pm 0.40)^{*}$ & $0.54( \pm 0.03)^{*}$ & $0.12( \pm 0.005)$ & $0.27( \pm 0.01)^{*}$ \\
\hline 120 & $3.27( \pm 0.28)^{*}$ & $0.66( \pm 0.01)^{*}$ & $0.14( \pm 0.01)$ & $0.25( \pm 0.01)^{*}$ \\
\hline 180 & $3.06( \pm 0.13)^{*}$ & $0.54( \pm 0.03)^{*}$ & $0.14( \pm 0.007)$ & $0.24( \pm 0.02)^{*}$ \\
\hline 240 & $3.92( \pm 0.22)^{*}$ & $0.47( \pm 0.05)^{*}$ & $0.08( \pm 0.00)$ & 0.007 \\
\hline
\end{tabular}

* Significant by $t$ test $(\mathrm{p} \leq 0.05)$. Values in parentheses represent the standard error for the average. $\mathrm{K}_{\mathrm{t}}$ and $\mathrm{K}_{\mathrm{a}}$ are the grouping coefficients related to wheat with ryegrass, respectively.

In wheat, the infestation of Chenopodium albumwith pure stand populations of 64 and $128 \mathrm{~m}^{-2}$ caused more losses in the culture productivity in doses of 120 and $60 \mathrm{~kg} \mathrm{~N} \mathrm{ha}^{-1}$, respectively. According to these authors, within low populations (up to 32 plants $\mathrm{m}^{-2}$ ), the increase in nitrogen doses benefited wheat, resulting into a higher culture/weed balance in the $120 \mathrm{~kg} \mathrm{~N} \mathrm{ha-1}$ dose.

Evaluating the competitiveness and the response to nitrogen fertilization in ryegrass and wheat, an increase in the competitiveness of ryegrass was observed, where populations of 100 plants $\mathrm{m}^{-2}$ reduced the production of wheat by $30 \%$ and $20 \%$, with and without nitrogen fertilization, respectively (Scursoni et al., 2012). In turn, when the proportion of the culture is higher, there is generally an increase of the culture competitiveness over the weed, as it happened in barley and L. rigidum, when the culture presented a higher number of plants over the weed, with the consequent reduction in the morphological variables of the competitor (Ponce, 1998).

According to the results, it is possible to deduce that the competition between culture and ryegrass by $\mathrm{N}$ caused mutual damages, but the culture showed greater competitiveness than the weed, regardless of the $\mathrm{N}$ dose. The use of doses up to $120 \mathrm{~kg} \mathrm{~N} \mathrm{ha}^{-1}$ increased the evaluated variables for wheat and ryegrass. On the other hand, interspecies competition and nitrogen, in higher than $120 \mathrm{~kg} \mathrm{~N} \mathrm{ha}^{-1}$ doses, reduced the mass of the aerial part dry matter and the leaf area of both studied species.

\section{REFERENCES}

Abouziema H.F. et al. Effect of nitrogen rates and weed control treatments on maize yield and associated weeds in sandy soils. Weed Technol. 2007;21:104-53.

Andreasen C., Litz A.S., Streibig J.C. Growth response of six weed species and spring barley (Hordeum vulgare) to increasing levels of nitrogen and phosphorus. Weed Res. 2006;46:503-12.

Bianchi M.A., Fleck N.G., Lamego F.P. Proporção entre plantas de soja e plantas competidoras e as relações de interferência mútua. Ci Rural. 2006;36:1380-7.

Blackshaw R.E. et al. Differential response of weed species to added nitrogen. Weed Sci. 2003;5:532-9.

Blackshaw R.E., Molnar L.J., Janzen H.H. Nitrogen fertilizer timing and application method affect weed growth and competition with spring wheat. Weed Sci. 2004;52:614-22.

Blackshaw R.E., Brandt R.N. Nitrogen fertilizer rate effects on weed competitiveness is species dependent. Weed Sci. 2008;56:743-7.

Burgos N.R. et al. Competitive N uptake between rice and weedy rice. Field Crop Res. 2006;99:96-105. 
Cathcart R.J., Swanton C.J. Nitrogen management will influence threshold values of green foxtail (Setaria viridis) in corn. Weed Sci. 2004;51:975-86.

Comissão Brasileira de Pesquisa de Trigo e Triticale. Informações técnicas para trigo e triticale - safra 2011 e $4^{\mathrm{a}}$ Reunião da Comissão Brasileira de Pesquisa de Trigo e Triticale. 2011.

Companhia Nacional de Abastecimento - Conab. Acompanhamento da safra brasileira de grãos. [accessed on: Mar 2016]. Available on: http://www.conab.gov.br/.

Cousens R. Aspects of the design and interpretation of competition (interference) experiments. Weed Technol. 1991;5:664-73.

Dhima K.V., Eleftherohorinos I.G. Influence of nitrogen on competition between winter cereals and sterile oat. Weed Sci. 2001;49:77-82.

Ditomaso J.M. Approaches for improving crop competitiveness through the manipulation of fertilization strategies. Weed Sci. 1995;43:491-7.

Dodamani B.M., Das T.K. Density and nitrogen effects on interference and economic threshold of common lambsquarters in wheat. J Pest Sci. 2013;86:611-9.

Empresa Brasileira de Pesquisa Agropecuária - Embrapa. Centro Nacional de Pesquisa de Solos. Sistema brasileiro de classificação de solos. $2^{\mathrm{a}}$.ed. Rio de Janeiro: Embrapa Solos, 2009. 412p.

Evans S.P. et al. Nitrogen application influences the critical period for weed control in corn. Weed Sci. 2003;51:408-17.

Hoffman M.L., Buhler D.D. Utilizing sorghum as functional model of crop-weed competition. I. Establishing a competitive hierarchy. Weed Sci. 2002;50:466-72.

Jornsgard B. et al. Influence of nitrogen on competition between cereals and their natural weed populations. Weed Res. 1996;36:461-70.

Lamego F.P. et al. Habilidade competitiva de cultivares de trigo com planta daninhas. Planta Daninha. 2013;31:521-31.

Large E.C. Growth stages in cereals. Illustration of the Feeks scale. Plant Pathol. 1954;3:128-9.

Lemerle D. et al. Genetic improvement and agronomy for enhanced wheat competitiveness with weeds. Aust J Agric Res. 2001;52:527-48.

Liebman M., Janke R.R., Francis C.A. Sustainable weed management practices. In: Francis C.A. et al., editors. Sustainable agriculture in temperate zones. New York: John Wiley and Sons, 1990. p.111-43.

Mishra J.S., Kurchania P. Nutrient concentration in mustard and associated weeds as influenced by nitrogen levels, planting geometry and weed control methods. Indian J Plant Physiol. 2001;6:386-9.

Paula J.M. et al. Competição de trigo com azevém em função de épocas de aplicação e doses de nitrogênio. Planta Daninha. 2011;29:557-63.

Ponce G.R. Competition between barley and Lolium rigidum for nitrate. Weed Res. 1998;38:453-60.

Radosevich S.R. et al. Ecology of weeds and invasive plants: Relationship to agriculture and natural resource management. $3^{\text {rd }}$.ed. New York: John Wiley \& Sons, 2007. 454p.

Rigoli R.P. et al. Habilidade competitiva de trigo (Triticum aestievum) em convivência com azevém (Lolium multiflorum) ou nabo (Raphanus raphanistrum). Planta Daninha. 2008;26:93-100.

Santos B.M. et al. Influence of purple nutsedge (Cyperus rotundus) density and nitrogen rate on radish (Raphanus sativus) yield. Weed Sci. 1998;46:661-4.

Scursoni J.A. et al. Italian ryegrass (Lolium multiflorum Lam.) density and $\mathrm{N}$ fertilization on wheat (Triticum aestivum L.) yield in Argentina. Crop Prot. 2012;32:36-40.

van Delden, A. et al. The influence of nitrogen supply on the ability of wheat and potato to suppress Stellaria media growth and reproduction. Weed Res. 2002;42:429-45. 